\title{
From Tampere to The Hague and beyond: towards the Stockholm Programme in the area of freedom, security and justice
}

\section{Laviero Buono}

Published online: 4 September 2009

(C) ERA 2009

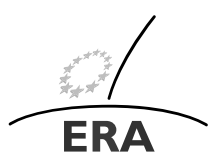

EUROPÄISCHE RECHTSAKADEMIE

ACADEMY OF EUROPEAN LAW ACADEMIE DE DROIT EUROPEEN ACCADEMIA DI DIRITTO EUROPEO TRIER - TREVES - TREVIRI

\section{Introduction}

Five years after the creation of the justice and home affairs (JHA) pillar of the European Union by the Treaty of Maastricht in 1992, the Treaty of Amsterdam of 1997 committed the Union to establishing a common area of freedom, security and justice (AFSJ), with matters of criminal justice, policing, asylum and immigration at its heart. The first multi-annual programme in the AFSJ, known as 'The Tampere Programme' ${ }^{1}$ provided the political mandate and the overall policy agenda for initial action towards establishing the AFSJ over the period 1999-2004. The main objective was the approximation of procedural and substantive law to facilitate mutual recognition by creating common minimum standards for the protection of individual rights.

Under the Tampere Programme, mutual recognition was to become the cornerstone of judicial cooperation in criminal matters within the Union. This was reflected in the landmark judgment of the Court of Justice in Gözütok and Brugge in 2003, where the Court ruled that " $[\mathrm{t}]$ here is a necessary implication that the Member States have mutual trust in their criminal justice systems and that each of them recognises the criminal law in force in the other Member States even when the outcome would be different if its own national law were applied."2

\footnotetext{
${ }^{1}$ Presidency Conclusions-Tampere, 15 and 16 October 1999.

${ }^{2}$ Joined Cases C-187/01 and C-385/01 Gözütok \& Brugge [2003] ECR I-5689, paragraph 33.

L. Buono $(\varangle)$

Head of Section-Public and Criminal Law, Academy of European Law, Metzer Allee 4, 54295

Trier, Germany

e-mail: lbuono@era.int
} 
In November 2004, the second multi-annual programme in the AFSJ, known as 'The Hague Programme' 3 was endorsed by the European Council for the period 2005-2009. In order to put the programme into practice, the European Commission was invited to present an Action Plan, ${ }^{4}$ setting out concrete implementing measures and actions together with a timetable for their adoption. The Commission Communication identified, from among the general orientations set out in the Programme, ten specific priorities upon which it believed efforts should be concentrated. These included: fundamental rights and citizenship, the fight against terrorism, asylum, immigration, civil and criminal justice and combating organised crime. Since 2005, the Commission has published three annual reports, known as Scoreboards, on the implementation of the Hague Programme. According to the most recent Scoreboard, ${ }^{5}$ progress in judicial and police cooperation in criminal matters has been rather slow, while developments in migration, border management and the fight against terrorism have been more satisfactory.

With the Hague Programme soon coming to an end, what should be the new priorities in European criminal justice for the next five years from 2010-2014? How can the current legislation be improved or simplified? How can existing instruments be made more effective?

With a view to establishing responses to those questions and to reflecting more generally on the future direction of EU justice and home affairs cooperation, the Portuguese Presidency of the Council in the second semester of 2007 set up high level advisory groups, including one on justice and one on home affairs, called the Future Groups. Each group was comprised of the Vice-President of the European Commission responsible for justice, freedom and security, the Ministers responsible for interior matters (or justice) of each Member State holding the EU Presidency from 2007 to 2009, as well as one representative of each of the presidency troika from the beginning of 2010 to June 2011, namely Spain, Belgium and Hungary. Member States with a common-law legal system designated experts who participated as observers.

Acting in an advisory capacity, ${ }^{6}$ the Future Groups submitted observations to EU policy makers on issues such as: combating terrorism and organised crime, control of external EU borders, biometric data, the use of new technologies and the external dimension of JHA. ${ }^{7}$ In the light of the reports of the Future Groups, the European Commission, in September 2008, launched a wide-ranging public consultation ${ }^{8}$ with

\footnotetext{
${ }^{3}$ Presidency Conclusions-Brussels, 4 and 5 November 2004.

${ }^{4}$ Communication from the Commission to the European Parliament-The Hague Programme: Ten priorities for the next five years. The Partnership for European renewal in the field of Freedom, Security and Justice (COM (2005) 184 final).

${ }^{5}$ Communication from the Commission to the Council and the European Parliament-Report on implementation of the Hague programme for 2007 (COM(2008) 373 final).

${ }^{6}$ It is worth noting that the work and the reports of the Groups were explicitly stated not to be intended to prejudice the Commission's right of initiative or replace the Council structure and/or EU decision-making.

${ }^{7}$ See full reports: Report of the Informal High-Level Advisory Group on the Future of European Home Affairs Policy (Council of the EU, document 11657/08 JAI 373) and High-Level Advisory Group on the Future of European Justice Policy-Proposed Solutions for the Future EU Justice Programme (Council of the EU, document 11549/08, JAI 369).

${ }^{8}$ The public consultation application with all the questions can be accessed at: http://ec.europa.eu/justice_ home/news/consulting_public/news_consulting_0001_en.htm.
} 
a view to incorporating a broader range of perspectives into its reflections on the new Stockholm Programme. The European Commission received 9 reports from Member States, 46 submissions from stakeholders and civil society and 770 written comments from citizens of all Member States. ${ }^{9}$

The Communication of the European Commission was published on 12 June $2009^{10}$ and it is now expected that the Stockholm Programme will be formally adopted in November 2009. In the light of the expected adoption of the Stockholm Programme, and bearing in mind the pending ratification of the Treaty of Lisbon, ${ }^{11}$ this issue of ERA Forum is devoted to the debate on the current direction of EU criminal justice policy. All articles are based on papers delivered by eminent experts at recent ERA conferences dealing, respectively, with the preparation of the Stockholm Programme and with three other topics that, in all likelihood, mutatis mutandis, will be among the key priorities of the new Programme: the protection of vulnerable victims, the anti-corruption policy of the EU and the fight against cybercrime.

\section{Preparing the Stockholm Programme}

On 25-26 May 2009, the ERA hosted a high-level conference in Trier entitled: New Horizons for EU Criminal Justice-from Tampere to the Stockholm Programme. At this conference, high-ranking representatives of the EU institutions, legal professionals, policy experts and academics came together to discuss the key priorities for the Stockholm Programme as regards EU criminal law. ${ }^{12}$ At the heart of the debate was the question of how cross-border investigations and prosecutions in criminal matters can be improved. This issue of the ERA Forum contains two articles based on presentations delivered at the seminar.

The paper of Ivan Bizjak, Director General for Justice and Home Affairs at the General Secretariat of the Council of the EU, discusses the proposed solutions contained in the reports of the Future Groups. The author presents the main findings of the Groups in five clusters: better protection of citizens (including citizens' rights in the EU, child protection and data protection), access to justice (including e-justice and criminal records), the fight against organised crime, the external dimension of

\footnotetext{
${ }^{9}$ See http://ec.europa.eu/justice_home/news/consulting_public/0001/contributions/background_paper_en. pdf.

${ }^{10}$ Communication from the Commission to the European Parliament and the Council-An area of freedom, security and justice serving the citizen (COM (2009) 262/4).

${ }^{11}$ At the time of writing, it remains uncertain whether, and if so, when, the Treaty of Lisbon will enter into force. The only certainty is that the new Treaty, once in force, will have a direct and immediate impact on all matters pertaining to the area of freedom, security and justice. EU competences in the field of judicial cooperation in criminal matters will be broadened, the co-decision legislative procedure will become applicable as a result of the abolition of the three-pillar structure, the set of legislative instruments available will be strengthened and the roles of the European Commission and Parliament and the jurisdiction of the European Court of Justice will be greatly enhanced. For more details see Crowe, R.: 'The Treaty of Lisbon: A Revised Legal Framework for the Organisation and Functioning of the EU', ERA Forum (2008) 9: 163-208.

${ }^{12}$ The implications of the Stockholm Programme for judicial cooperation in civil matters will be discussed at another ERA conference to be held in Trier on 26-27 November 2009.
} 
the European area of justice and the enhancement of legal certainty in family, commercial and civil law. Mr. Bizjak also touches upon those horizontal issues that are of importance for the further development of the area of freedom security and justice, such as the role, the structure and the working methods of the JHA Council, better communication to the public, quality of legislation and the need for a clear use of language. An ambitious but realistic programme in the area of criminal justice seems to be a common orientation, he concludes.

The contribution of the Spanish Prosecutor General, Cándido Conde-Pumpido Touron, emphasises the importance of a central prosecution authority in a Union with common rules and institutions and with no internal borders. Mr. Conde-Pumpido Touron considers the communication between the Public Prosecution Ministries of the EU to be of crucial importance. Meetings such as the Eurojustice conferences (informal fora which gather together the EU Prosecutors General), the Conferences of Presidents of Supreme Courts and Prosecutors General of the EU and the recently established Supreme Courts' Prosecutors Network, have certainly made it possible to establish fluent channels of communication between national prosecution authorities. Nonetheless, intercommunication between European Public Ministries is, alone, insufficient. There is a clear necessity to coordinate prosecution activities to comply with public demands. This can be done, the author argues, by the operational reinforcement of Eurojust and the creation, ex novo, of a High Level Consultative Forum or Advisory Group, made up of high ranking authorities of the various EU Public Prosecutors Ministries. Finally, looking at the "New horizons for EU Criminal Justice", the author also elaborates on the possibilities for establishing the European Public Prosecutor's Office, an idea contained in the Treaty of Lisbon, that has been included among the priorities of the upcoming Spanish Presidency of the EU in the first semester of 2010.

\section{Protection of vulnerable victims and their standing in criminal proceedings}

On 17-18 March 2009, in the framework of the Czech Presidency of the EU, the Ministry of Justice of the Czech Republic, in co-operation with ERA, hosted a conference in Prague entitled: Protection of vulnerable victims and their standing in criminal proceedings. The event was attended by approximately 60-70 participants, made up of legal practitioners, representatives of governments of the Member States, representatives of the institutions of the EU and the Council of Europe as well as legal academics and representatives of NGOs. The objective of the conference, which included three specially-designed workshops, was to review the current legal framework and to assess possible future improvements in the overall European approach to the issue of vulnerable victims. ${ }^{13}$

The conference discussed the revision of Framework Decision 2001/220 on the standing of victims in criminal proceedings. ${ }^{14}$ That Framework Decision was in-

\footnotetext{
${ }^{13}$ See Presidency conclusions on the Conference for the protection of vulnerable victims and their standing in criminal proceedings-Prague 17/18 March 2009 (Council of the EU, document 9868/09, Droipen 32).

${ }^{14}$ Council Framework Decision 2001/220/JHA on the standing of victims in criminal proceedings (OJ L 82 of 22 March 2001, p. 1).
} 
tended as a first step towards providing a response at EU level to the issue of the proper care of victims of crime by laying down a set of minimum requirements for the Member States to improve the services on offer to all victims of crime and to their families. ${ }^{15}$ Although Member States were under an obligation to implement Framework Decision 2001/220 by March 2006, the overall result has been rather unsatisfactory. Partly this is because some of the articles in the Framework Decision were vague and did not contain real obligations and partly it is because implementation was not properly effected by national authorities in the Member States.

On 21 April 2009, the European Commission adopted its second report ${ }^{16}$ on the implementation of the 2001 Framework Decision. ${ }^{17}$ The report shows that, in general, the Member States simply informed the Commission that their national measures already complied with the obligations arising from the European instrument. Some Member States also stated that they had fulfilled their obligations through nonbinding acts such as guidelines on best practices, charters and instructions to public prosecutors. The European Commission concluded that the implementation of the Framework Decision in Member States was not satisfactory.

In her paper in this issue, Professor Jenny McEwan analyses one of the key topics discussed during the Prague conference, namely the admissibility of the testimony of vulnerable victims in criminal proceedings. What are the relevant instruments that apply? Are those instruments in force in all Member States? Can the evidence provided be used in foreign courts? Professor McEwan highlights the most relevant European instruments, with a particular focus on the provisions of Framework Decision $2001 / 220$ on the standing of victims in criminal proceedings. She observes that, despite a manifest willingness to co-operate, the EU is still a very long way from having achieved a system where the collection of evidence can effectively be requested by the competent authorities of one Member State and then delivered to them (and used in trial) by the authorities of another Member State. Of particular interest in her paper is the reference to the controversial definition of "vulnerable victim". Who is vulnerable? ${ }^{18}$ In England "vulnerable" is understood to mean principally children and mentally or otherwise disabled witnesses and witnesses in fear or distress. ${ }^{19}$ The author argues that in order to guarantee effective protection across the whole of the EU, all criminal proceedings should be accessible, flexible and supportive of the needs of

\footnotetext{
${ }^{15}$ In this regard, it should be noted that the conference also discussed the expected revision of two related legal instruments: Council Framework Decision 2004/68/JHA on combating the sexual exploitation of children and child pornography (OJ L 13 of 20 January 2004, p. 1), as well as Council Framework Decision 2002/629/JHA on combating trafficking in human beings (OJ L 203 of 1 August 2002, p. 1).

${ }^{16}$ The European Commission published a first report on 16 February 2004 (COM(2004) 54 final/2). This first report examined the transposition of the 2001 Framework Decision into national legislation. By March 2003, only 10 Member States had reported to the European Commission on transposition into their national law.

${ }^{17}$ Report from the European Commission pursuant to Article 18 of the Council Framework Decision of 15 March 2001 on the standing of victims in criminal proceedings (COM(2009) 166 final).

${ }^{18}$ A common European definition of "vulnerable victims" was vigorously debated in the working groups' discussions during the conference in Prague, especially as some Member States already have a definition of vulnerable victims in their own legislation.

${ }^{19}$ See Youth Justice and Criminal Evidence Act, 1999.
} 
vulnerable victims. However, as it stands now, without a set of uniform definitions and rules at EU level, the variations among the Member States makes it very difficult to obtain justice for such victims.

Another topic which was examined extensively during the conference relates to the protection of vulnerable victims against secondary victimisation. This issue is commented on in the paper of Professor Bernd Schünemann. Secondary victimisation means that the different stages of the criminal proceedings might cause mental harm to the victim. Examples are offered by repeated hearings, aggressive interrogation techniques and/or intrusive medical investigations, direct confrontation with the defendant, etc. The author notes the German example, where, after a series of amendments to the German code of criminal procedure, victims now enjoy an extremely high level of protection. The paradox is that this attitude might turn into a sort of erosion of the principle of fair trail as defined by Article 6 of the European Convention on Human Rights. Strengthening victims' procedural rights can transform the victim into an 'accessory prosecutor'. This would threaten the balance of the criminal procedure and, ultimately, the presumption of innocence. It is therefore necessary, Professor Schünemann argues, to draw a clear line between the rules governing the right to a fair trial and the rules concerning the effective participation of victims in criminal proceedings.

It is further worth noting that Article 8 of Framework Decision 2001/220 on the standing of victims in criminal proceedings gave rise in 2005 to the well known Pupino case before the Court of Justice. ${ }^{20}$ Ms Maria Pupino, a nursery school teacher, was accused of mistreatment of some of her pupils who were less than five years old. In order to avoid imposing testimony during the main trail, the Italian Public Prosecutor requested that the alleged victims be heard during the preliminary enquiries. This would avoid secondary victimisation of the children. In Italy, however, this manner of giving testimony was possible only in trials for sexual abuse, which was so not the case of Ms Pupino. The judge in charge of the preliminary enquiries at the Tribunale di Firenze referred the case to the Court of Justice, which in its judgment held that: "It would be difficult for the European Union to carry out its task effectively if the principle of loyal cooperation, requiring, in particular, that Member States take all appropriate measures, (...) were not also binding in the area of police and judicial cooperation in criminal matters". ${ }^{21}$ On this basis, the Italian judge was required to make every effort to interpret the national rules in harmony with the requirements of the Framework Decision and a substantial contribution was thereby made to the de facto convergence of the effects in national law of instruments adopted across the first and third pillars. ${ }^{22}$

Reference to the Pupino case and to its rapprochement effect is made in the Professor Bruno Nascimbene's paper. The author begins by pointing at the lack of a fully effective system of judicial protection in the second and third pillars of the EU.

\footnotetext{
${ }^{20}$ Case C-105/03 Criminal proceedings against Maria Pupino [2005] ECR I-5285.

${ }^{21}$ Case C-105/03 Criminal proceedings against Maria Pupino [2005] ECR I-5285, paragraph 42.

${ }^{22}$ In the wake of the Pupino case and concerning the interpretation of national law in conformity with EU Framework Decisions, see also case C-467/05, criminal proceedings against Giovanni dell'Orto [2007] ECR I-5557.
} 
However he acknowledges how the Court of Justice, through its recent jurisprudence, (reference is especially made to the above-mentioned Pupino case and to the Segi case $^{23}$ ) succeeded in making judicial protection more effective and exhaustive in the area of freedom, security and justice. This impasse between the pillars, not only at a procedural level, but also with respect to the regime of judicial protection, will end if the Treaty of Lisbon ever enters into force. It will then be possible, the author concludes, for legal instruments adopted in criminal matters to be subjected to the same set of remedies as are currently available in the first pillar.

\section{The anti-corruption policy of the European Union: focus on asset recovery}

In 2008, for the third year in a row, ERA successfully applied for funding under OLAF's Hercule Programme ${ }^{24}$ to implement the third annual forum on Combating corruption and fraud in the EU. ${ }^{25}$ These annual fora aim at facilitating a sharing of experiences among authorities of the Member States (especially among judges, prosecutors and civil servants) in dealing with issues that relate to the protection of the financial interests of the Union.

The third forum, held in Trier on 18-19 February 2009, brought together approximately 100 legal practitioners and experts, many of them from the national associations for the protection of the financial interests of the European Communities. ${ }^{26}$ The event aimed mainly at promoting, facilitating and supporting European and international cooperation and technical assistance in the prevention of and fight against corruption. This year's forum had a specific focus on asset recovery, which has been singled out as "a fundamental principle" of the United Nations Convention against Corruption. ${ }^{27}$ The seminar offered first and foremost an overview of the major international, European and national initiatives in asset recovery. It then focused on best practices for more effective asset recovery in Member States and, finally, it presented the practitioners' perspective on what makes those procedures so difficult in practice. The view of the defence and the role of Eurojust in this context was also emphasised. The EU dimension of anti-corruption efforts was, however, placed in a very much broader context, with particular reference being made in the discussions to the importance of ratification by all EU Member States of the UN Convention against corruption.

\footnotetext{
${ }^{23}$ Case C-355/04 P Segi and others v Council [2007] ECR I-1657.

${ }^{24}$ The "Hercule Programme" is a Community action programme to promote activities in the field of the protection of the Community's financial interests (OJ L 143 of 30 April 2004, p. 9). For OLAF calls for proposals under the Hercule Programme see http://ec.europa.eu/anti_fraud/programmes/index_en.html.

${ }^{25}$ The forth Forum is already scheduled for February 2010 (further details will be forthcoming on the ERA website: www.era.int).

${ }^{26}$ The 2009 programme developed by ERA attracted the interest also of applicants from many non-EU countries such as Croatia, Turkey, Switzerland, Norway, Liechtenstein and Russia. The large number of countries, and therefore legal jurisdictions represented, helped attain the goal of the forum to facilitate a broad exchange of experiences between representatives of the EU Member States, candidate countries and third states.

${ }^{27}$ See General Assembly resolution 58/4 of 31 October 2003-United Nations Convention against Corruption.
} 
This issue of the ERA Forum contains three papers selected from the abovementioned event, concerning, respectively, the international and European dimension of asset recovery, the national dimension of asset recovery from a British perspective and the Alamieyeseigha case-study.

The paper by Alan Bacarese provides a general overview of the current international and EU legal framework for the confiscation of proceeds of crime. A particular emphasis is placed on international cooperation, both from a practical perspective and in terms of the main international instruments that apply, such as the UN Convention against corruption. The article also identifies the main actors in this area and what they have managed to do over the course of the last year or so. It points at a number of EU legislative initiatives that assist in the battle to improve cooperation in asset recovery, such as the recent EU initiative on the creation of Asset Recovery Offices. ${ }^{28}$ The author finds that, although the notion of recovering stolen property is not a new phenomenon, organised crime groups and other criminal networks continue to amass substantial profits with little prospect of being caught. In this respect, Alan Bacarese defines the discrepancies in the monies that continue to be made by criminals through corruption, fraud and other offences and the monies recovered by law enforcement agencies as "dramatic".

Switching focus from the international and European to the national level, David Dickson's paper presents the United Kingdom example. He reports that in the period since the introduction of the Proceeds of Crime Act 2002 (POCA) ${ }^{29}$ until 31 March 2008 , the Courts in Scotland have ordered the confiscation of $£ 13.5 \mathrm{~m}$ worth of assets in criminal confiscation cases and $£ 7.4 \mathrm{~m}$ in civil confiscation orders. In England, between April 2007 and February 2008, a total of $£ 225,870,000$ was confiscated as the proceeds of crime, with the Court making 4504 orders. Like at the transnational level, it is considered at national level that one of the means to reduce crime is to remove the financial benefit from criminal conduct, ${ }^{30}$ thus also reducing the ability to finance future criminal conduct. In the UK, the POCA introduced, inter alia, the following changes to the existing system of forfeiture: it consolidated the existing legislation in the area of confiscation, it established the National Asset Recovery Agency (ARA), ${ }^{31}$ it extended the powers of the criminal courts to make confiscation orders and it introduced enhanced post-conviction powers and new and stricter money laundering offences. The author emphasises that the UK has transposed Framework Decision $2003 / 577,32$ although the relevant provisions have not yet entered into force. At any

\footnotetext{
${ }^{28}$ Council Framework Decision 2007/845/JHA concerning cooperation between Asset Recovery Offices of the Member States in the field of tracing and identification of proceeds from, or other property related to crime (OJ L 332 of 18 December 2007, p. 103) decreed that each Member State would, by the 18th December 2008, establish a national Asset Recovery Office (ARO).

${ }^{29}$ The Act entered into law in the United Kingdom (although with separate provisions for Scotland) on 24 July 2002, with its main provisions coming into effect on 24 February 2003.

${ }^{30}$ Conditions that define criminal lifestyle are contained in Section 75 of the Proceeds of Crime Act 2002.

${ }^{31}$ The Agency was originally established to trace and investigate the ownership of property deriving from criminal activity. Since April 2008, a leading role in criminal confiscation is now played by the Serious Organised Crime Agency (SOCA), which was created on 1 April 2006. In Scotland, this role is within the remit of the Prosecutor.

${ }^{32}$ Council Framework Decision 2003/577/JHA of 22 July 2003 on the execution in the European Union of orders freezing property or evidence (OJ L 196 of 2 August 2003, p. 45).
} 
rate, he notes that those provisions relate to the freezing of property as evidence and that, therefore, the ultimate recovery of such evidence will still need to proceed by the ordinary route of a mutual legal assistance request.

In that regard, a concrete example of international cooperation through mutual legal assistance is illustrated in the third article, concerning the Alamieyeseigha case. The paper, written jointly by James Maton and Tim Daniel, is a case-study of an ultimately successful effort to recover the corruptly acquired assets of Mr Diepreye Peter Solomon Alamieyeseigha, a former Nigerian State Governor, through the use of a range of civil and criminal asset recovery mechanisms. In reconstructing the accumulation of his wealth, the authors report that in a mere six years, from 1999 to $2005,{ }^{33}$ Chief Alamieyeseigha's portfolio of foreign assets (properties in the UK, bank accounts in Cyprus, Denmark and the United States, investments and cash) increased in value by in excess of $€ 11$ million. ${ }^{34}$ In September 2005, he was arrested in London. Two months later he managed to escape, but in December 2005 he was impeached in Nigeria. ${ }^{35}$ The full set of mechanisms (criminal restraining orders on assets, request for mutual legal assistance, criminal confiscation of assets, civil forfeiture of cash and world-wide freezing injunctions and others) are duly presented in the paper by the authors, who conclude that speedy investigations carried out by the Nigerian and the British authorities, effective and quick international execution of requests for mutual legal assistance and effective co-operation between law enforcement officers and Nigerian lawyers were among the main reasons for the success of the recovery procedure.

\section{The fight against cybercrime}

The phenomenon of criminal acts committed through use of internet technologies is often described by terms such as "cybercrime", "computer crime" or "high-tech crime". These are criminal activities that use a computer either as an instrument, target or a means for committing further crimes. Due to the global nature of information networks, there is nowadays ever-growing vulnerability to cybercrime. To tackle this threat, traditional mutual assistance and operational law enforcement cooperation often prove ineffective and inadequate. Addressing the challenge of cybercrime is a key priority for the European Union for the coming years and the security of 'European information systems', as defined in the Council Framework Decision 2005/222, ${ }^{36}$ is of paramount importance.

The seminar held in Trier on 14-15 May 2009 entitled: Criminal exploitation of new technologies: an effective response to cybercrime was intended as a platform to

\footnotetext{
${ }^{33} \mathrm{Mr}$ Alamieyesigha took office in May 1999, when he declared an annual income of Nigerian Naira $1,500,000$ (approximately $€ 6.800$ ).

${ }^{34}$ This foreign wealth was in addition to substantial property holdings accumulated in Nigeria for $€ 6,5$ million. None of these foreign assets, and only limited domestic assets, were declared.

${ }^{35}$ Impeachment removed Mr Alamieyesigha's domestic immunity. He was arrested and remanded in custody. Nigeria's Economic and Financial Crimes Commission obtained a freezing injunction over his assets.

${ }^{36}$ Council Framework Decision 2005/222/JHA of 24 February 2005 on attacks against information systems (OJ L 69 of 16 March 2005, p. 67).
} 
debate and assess how European legislation in this field is applied in the different Member States and candidate countries and the perspectives for an effective Europewide campaign against cybercrime. The most recent European legal acts ${ }^{37}$ and complementary measures adopted for combating cybercrime were scrutinised. Ongoing co-operation with service providers and web societies such as Google, Microsoft and Yahoo! ${ }^{38}$ was also discussed.

In this issue of ERA Forum, we publish an article by Dr Marco Gercke, who in the course of the ERA seminar addressed the topics of copyright violations and cooperation between law enforcement agencies and internet service providers. $\mathrm{Dr}$ Gercke examines the initiatives that have been undertaken by the European Union and the Council of Europe to develop an adequate legal framework to address the challenge of cybercrime. A clear overview of recent legal developments at European Union and Council of Europe level is key for national authorities in order to update their domestic legal framework, since the separate and autonomous drafting of cybercrime legislation often results in significant duplication and waste of resources. In his paper, the author chronicles the main EU initiatives launched in this field, starting with the 1999 " $e$ Europe" initiative ${ }^{39}$ right up to the recent controversial EU Telecoms reform of 2008. ${ }^{40}$ As regards Council of Europe instruments, apart from the recent 2007 Convention on the protection of children, ${ }^{41}$ reference is made to the 2001 Convention on cybercrime. By May 2009, 46 States and 25 States around the world had signed and ratified the 2001 Cybercrime Convention.

\footnotetext{
${ }^{37}$ The seminar particularly focussed on three European legal acts: the Council of Europe Convention on Cybercrime (2001), Council Framework Decision 2005/222/JHA on attacks against information systems and Council Framework Decision 2004/68/JHA on combating the sexual exploitation of children and child pornography.

${ }^{38}$ To this extent, the seminar analytically discussed proposals to improve the efficiency of the 24/7 network of contact points (Art. 35 of the 2001 Council of Europe Convention on Cybercrime) set up in order to ensure the provision of immediate assistance for the purpose of investigations or proceedings concerning criminal offences related to computer systems and data.

${ }^{39}$ Communication on a Commission Initiative for the Special European Council of Lisbon, 23 and 24 March 2000- “ $e$ Europe: An Information Society For All” (COM(1999) 687).

${ }^{40}$ On this point, the author makes reference to the Commissions press release of 07.11.2008-Telecoms Reform: Commission presents new legislative texts to pave the way for compromise between Parliament and Council.

${ }^{41}$ Council of Europe Convention of 2007 on the Protection of Children against Sexual Exploitation and Sexual Abuse (CETS No. 201).
} 